\title{
POSTMORTEM HEPATIC GLYCOGENOLYSIS IN HYPERINSULINISM AND GLYCOGEN DISEASE ${ }^{1}$
}

\author{
BY H. P. G. SECKEL \\ (From the Department of Pediatrics, University of Chicago, Chicago)
}

(Received for publication May 22, 1939)

The fundamental pathology of von Gierke's glycogen disease (1) lies in the inhibition of in vivo and postmortem glycogenolysis of the liver and other organs. In the discussion of the pathogenesis of this disorder, hyperinsulinism has been time and again suggested since Wilder and his collaborators (2) described their famous case of pancreatogenic hyperinsulinism with severe spontaneous hypoglycemia and a very high liver-glycogen content. They hinted at a similar situation in the equally famous case of Parnas and Wagner (3). This case, concerning a 9-year-old girl with hepatomegaly, hypoglycemia, ketonuria, and retardation of growth, is now almost universally recognized as the first case of glycogen disease ever described in the literature before the final elucidation of the disorder by von Gierke in 1929 (1) (cf. the early case of Worster-Drought (4a), and especially that of Snapper and van Creveld (5)). It has been noticed, however, that in Wilder's case of carcinoma of the Langerhans islets with metastases to the liver, postmortem hepatic glycogenolysis was not determined and, as a matter of fact, has never yet been determined in the numerous cases of hyperinsulinism reported in the literature. It is the purpose of this communication to fill this gap by examining postmortem hepatic glycogenolysis in 2 cases of spontaneous hypoglycemia, one of which is almost certainly due to "pancreatogenic" hyperinsulinism, while the other will be tentatively classified as " neurogenic" hyperinsulinism.

\section{CASE REPORTS ${ }^{2}$}

Case 1. Albert R., 36 years, Number 195034. Admitted to the Department of Neuro-Surgery, University of Chicago, on March 21, 1938.

The patient had unexplained attacks of complete unconsciousness for quite some time which were revealed

\footnotetext{
1 This work was aided by a grant from the Douglas Smith Foundation for Medical. Research.

2 For more elaborate findings see later publication by N. B. Friedman and W. Sweet to whom the writer is greatly indebted for communicating the data.
}

to be typical seizures of spontaneous hypoglycemia. Blood sugar on fasting and during attacks was between 16 and $23 \mathrm{mgm}$. per cent; no glycosuria, no ketonuria. The liver was found to be grossly enlarged and nodular to palpation. The hypoglycemic seizures were immediately stopped or prevented by intravenous glucose infusions, but not by adrenalin injections. The daily glucose requirement by mouth and parenterally was about 600 grams. Under this regime, further hypoglycemic seizures were prevented; the body weight increased from 57.1 to $64.3 \mathrm{kgm}$. within three months in spite of the underlying carcinoma. Alimentary glucose tolerance test: high rise of blood sugar falling off very early to hypoglycemic levels. Adrenalin test (1 mgm. subcutaneously) : non-fasting blood sugar $73 \mathrm{mgm}$. per cent, after $20 \mathrm{~min}$ utes $98 \mathrm{mgm}$. per cent, after 45 minutes $65 \mathrm{mgm}$. per cent; slight vasomotor response. There was no abnormal sensitivity to insulin. The blood cholesterol was normal.

Clinical diagnosis. Spontaneous hypoglycemia, probably due to a pancreatic tumor. An exploratory laparotomy was done on April 15th. Innumerable white metastatic nodules were seen all over the liver. Following the ether anesthesia, the glucose requirement was considerably reduced for several days. During 24 hours preceding death, 580 grams of glucose were administered parenterally, the last dosage about 2 hours before death. Exitus on June 22, $1: 20$ p.m.

Autopsy (started 15 minutes after death). Carcinoma of the pancreatic islets with nodular metastases to the liver and other viscera. Histologically, there was no abnormal glycogen storage outside the liver and muscles. An insulin assay of the liver nodules was unsatisfactory.

Case 2. William M., 56 years, Number 206024. Admitted to the Department of Medicine, University of Chicago, on September 23, 1938.

The patient had supposedly uremic attacks with complete unconsciousness for about 8 weeks which were recognized as typical seizures of spontaneous hypoglycemia. Blood sugar on fasting and during attacks was between 26 and $34 \mathrm{mgm}$. per cent, occasionally higher (72 mgm. per cent); no glycosuria, no ketonuria. The hypoglycemic seizures were stopped and prevented by administration of large amounts of glucose by mouth and parenterally. Alimentary glucose tolerance test: High rise of blood sugar for about an hour falling off to around 30 mgm. per cent after $21 / 2$ hours. Adrenalin tests ( $1 \mathrm{mgm}$. subcutaneously) : fasting blood sugar $62 \mathrm{mgm}$. per cent, after 5, 15, and 60 minutes 58, 60 and $65 \mathrm{mgm}$. per cent respectively; $3 \mathrm{mgm}$. intravenously: non-fasting blood sugar $76 \mathrm{mgm}$. per cent, after 5,10 , and 40 minutes 84 , 
88 , and $78 \mathrm{mgm}$. per cent, respectively; intensive vasomotor response. Three $\mathbf{m g m}$. adrenalin intravenously did not arouse the patient from hypoglycemic coma. Blood cholesterol was $185 \mathrm{mgm}$. per cent. The liver was not enlarged to palpation. On x-ray examination a marked elevation of the right leaf of the diaphragm with corresponding compression atelectasis of the right lung was found.

Clinical diagnosis. Spontaneous hypoglycemia, presumably from a pancreatic adenoma. On October 17th, an exploratory laparotomy was done under spinal and ether anesthesia. No pancreatic tumor was discovered; the liver appeared to be normal; a biopsy was taken for chemical analysis. Postoperatively, 4 times 75 grams of glucose were administered parenterally without arousing the patient from unconsciousness. Exitus next morning at $8: 15$.

Autopsy (started at 10 a.m.). Massive fibroma on right top of the liver bulging the medial aspect of the right diaphragm; pancreas normal; no metastases anywhere. No autopsy of the brain was made. Histologically, no glycogen was stored except in liver and muscles. An insulin assay of the fibroma did not reveal any insulin.

\section{Chemical analyses}

Glycogen was determined in various organs with Pflueger's method as modified by Good, Kramer and Somogyi (6). The final estimation of glucose was made with Somogyi's modification (7) of Shaffer and Hartmann's method (factor 0.927). Blood glycogen was estimated with van Creveld's method (8a). All figures are based on duplicate determinations. Small pieces of tissue were put into dry ice immediately after the organs had been received at autopsy, i.e., 24 minutes after death in case 1 , and 2 hours and 40 minutes after death in case 2. In the animal experiments performed for control purposes, tissue pieces were put into dry ice 2 to 3 minutes after death. In both the human and animal experiments, unsliced pieces of one and the same liver lobe were preserved in a wet chamber, either at $37^{\circ} \mathrm{C}$. with toluene added to prevent bacterial growth, or at ice box temperature with no preservative added. The glycogen content was determined at various intervals in the liver tissue in order to obtain time curves of postmortem hepatic glycogenolysis. In Table I, the figures observed in the 2 clinical cases of hyperinsulinism are listed in conjunction with corresponding determinations in a few cases of glycogen disease reported in the literature as well as in normal rats and a rabbit. Liver glycogenolysis curves of the 3 categories are presented in Figures 1 and 2.

In both clinical cases of hyperinsulinism sliced liver specimens were suspended for 2 hours at $37^{\circ} \mathrm{C}$. in a phosphate-buffered salt solution at $\mathbf{p H} 7.4$ (for technique see Seckel (9a)). The following glycogen figures were observed in the liver slices: Case 1: At start (60 minutes after the liver was received) : 1.37 grams per cent; after 60 minutes $0.65 \mathrm{gram}$ per cent; after 120 minutes 0.53 gram per cent. By adding 1 per cent conjugated bile salts to the suspension solution, as has been done earlier with rat liver slices (Seckel, 9a), the 60 minutes glycogenolysis was increased to 0.396 gram per cent; 0.1 per cent bile salt and 4 units of insulin per cc. of solution proved to be ineffective. Case 2: At start (60 minutes after the liver was received) $\mathbf{3 . 0}$ grams per cent; after 60 minutes 2.81 grams per cent; after 120 minutes 1.85 grams per cent.

Finally, the proportion of lyo- and desmo-glycogen was determined in the two human livers by repeated extractions with boiling water according to Willstätter and Rohdewald's method (10). Liver pieces kept in the ice box for 6 days were used for this purpose. In Case 1, 20.7 per cent of the total liver glycogen was found to be desmo-glycogen and 79.3 per cent to be lyo-glycogen. In Case 2, the corresponding figures were 14.4 and 85.6 per cent. In a normal rat liver, 18 and 82 per cent were found respectively (Experiment Number 129). In fresh geese livers, Willstätter and Rohdewald found 10 to 13 and 87 to 90 per cent, respectively.

\section{COMMENT}

In Case 1, the blood glycogen figure was within normal limits (average for normal children 12.9 mgm. per cent (8a)). No glycogen was found in the mesenteric fat. In Schönen's (11) experiments in young dogs fattened on "glycogen mast,"

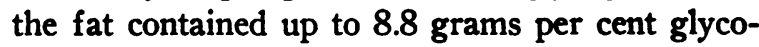
gen. Probably the patient's heart was glycogenfree because of the delay in chemical examination. The glycogen content of the rectus abdominis muscle (1.57 grams per cent) seems to be unusually high. In view of the large amount of glucose administered to the patient, the liver-glycogen content of 1.58 grams per cent appears to be rather low. However, it is still considerably above the indirect estimations of human liver glycogen at the moment of a "chronic death" as carried out by Popper and Wozasek (12a) and Burghard and Paffrath (13) (average of 0.65 gram per cent for "total carbohydrates"; for "glycogen" subtract 0.23 gram per cent). Furthermore, this patient's liver was filled with histologically glycogen-free metastatic nodules and was also invaded with tiny cell nests throughout those seemingly " normal" portions which were used for chemical examination. This not only accounts for the comparatively low glycogen content of the organ but also for the gross aberrations of individual figures in the curve of hepatic glycogenolysis (Table I, ice box temperature, 6- and 18-hour samples).

In Case 2, the liver fibroma was almost glycogen free on chemical analysis. The glycogen content 
of the rectus muscle ( 0.52 gram per cent), although smaller than in Case 1 , was still higher than might have been expected $2 \frac{1}{2}$ hours after death. Rather large amounts of glycogen were found in the liver not only at autopsy ( 3.52 grams per cent), but especially at biopsy (6.1 grams per cent). The latter finding is all the more remarkable as the biopsy specimen was taken after a long ether anesthesia which is known to mobilize glycogen from the liver (14), even in cases of pancreatogenic hyperinsulinism (2). In contrast to Case 2 , in Wilder's patient the liver glycogen was lower during ether anesthesia (3.49 grams per cent) than $2 \frac{1}{2}$ hours after death ( 8.25 grams per cent). The amount and time of glucose administrations during the day preceding operation or death may well play a part in determining the glycogen figures of such cases.

The curves of postmortem hepatic glycogenolysis of Cases 1 and 2, as presented in Table I and Figure 1, varied greatly according to the temperature applied. At $37^{\circ} \mathrm{C}$., glycogen dissimilation proceeded constantly and rapidly and was almost completed within 1 or 2 days. At ice box temperature, it proceeded much slower and more irregularly; after 6 days, about 50 per cent of the glycogen was still present. Since, as yet, the writer was unsuccessful in securing control figures

TABLE I

Glycogen content and postmortem glycogenolysis of various unsliced tissues (glycogen in grams per 100 grams of fresh tissue)

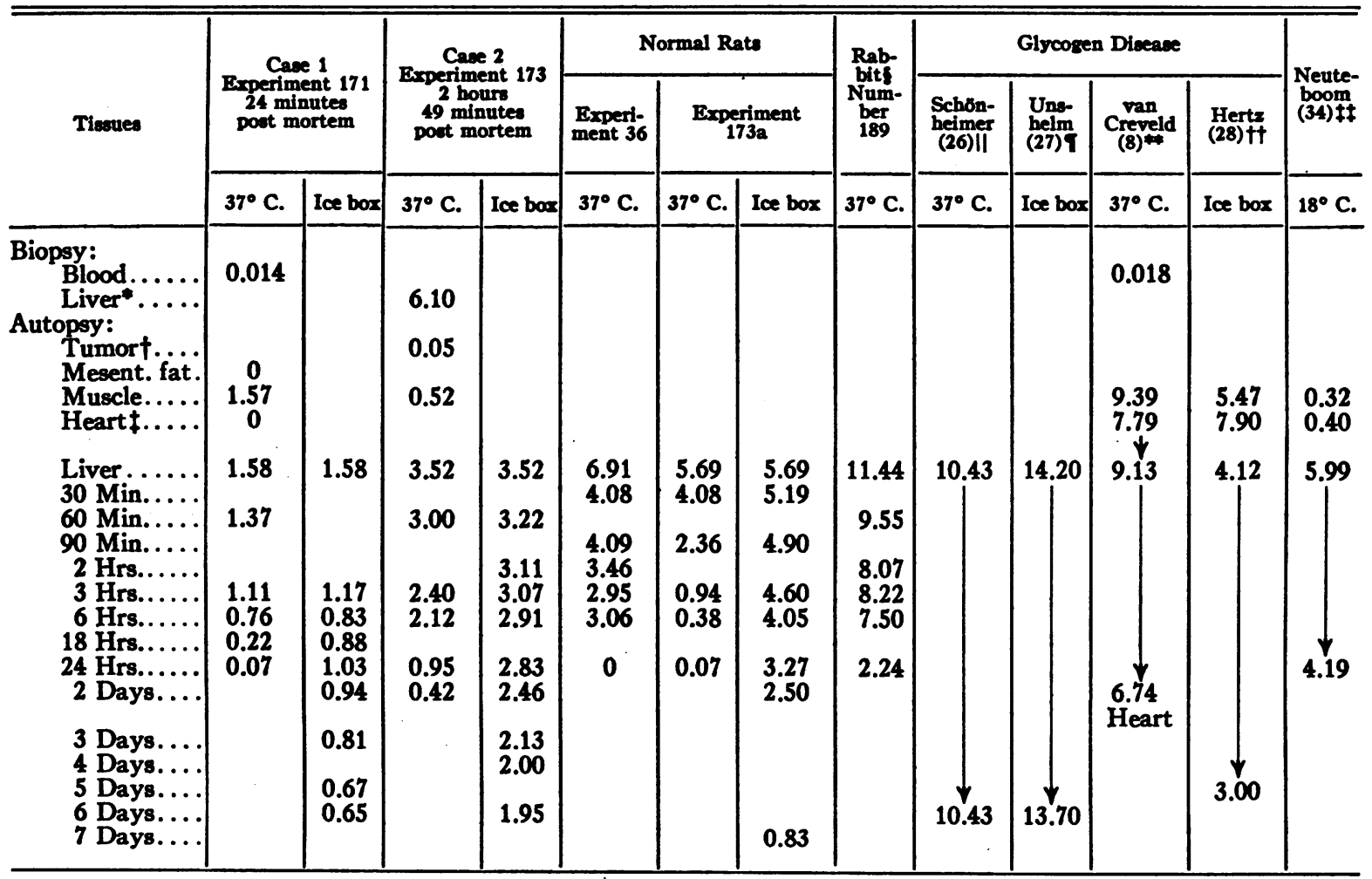

- Determination by Dr. R. Sternheimer, Department of Medicine.

+ Tumor kept on ice for $6 \frac{1}{3}$ hours before examination.

+ Heart of Case 1 examined about one hour after death.

This animal received 5 grams glucose daily in addition to the stock diet.

von Gierke's case of Hepatonephromegalia Glycogenica; autopsy 24 hours postmortem. Liver kept on ice for 4 additional days before the first glycogen determination was made by Schoenheimer.

I Case of Hepatomegalia Glycogenica; autopsy and glycogen determination 24 hours after death. Liver kept in ice box as pulp.

* Case of Cardiomegalia Glycogenica; autopsy and glycogen determination 24 hours postmortem.

tt Case of Cardiomegalia Glycogenica; heart kept on ice for 17 hours, muscle for 2 days and liver for 12 days after death. At ice box temperature, heart glycogen decreased very little within 6 days.

$¥$ Rabbit operated upon thoracic nerve segments (see text); start of glycogen determinations 5 hours after death. 


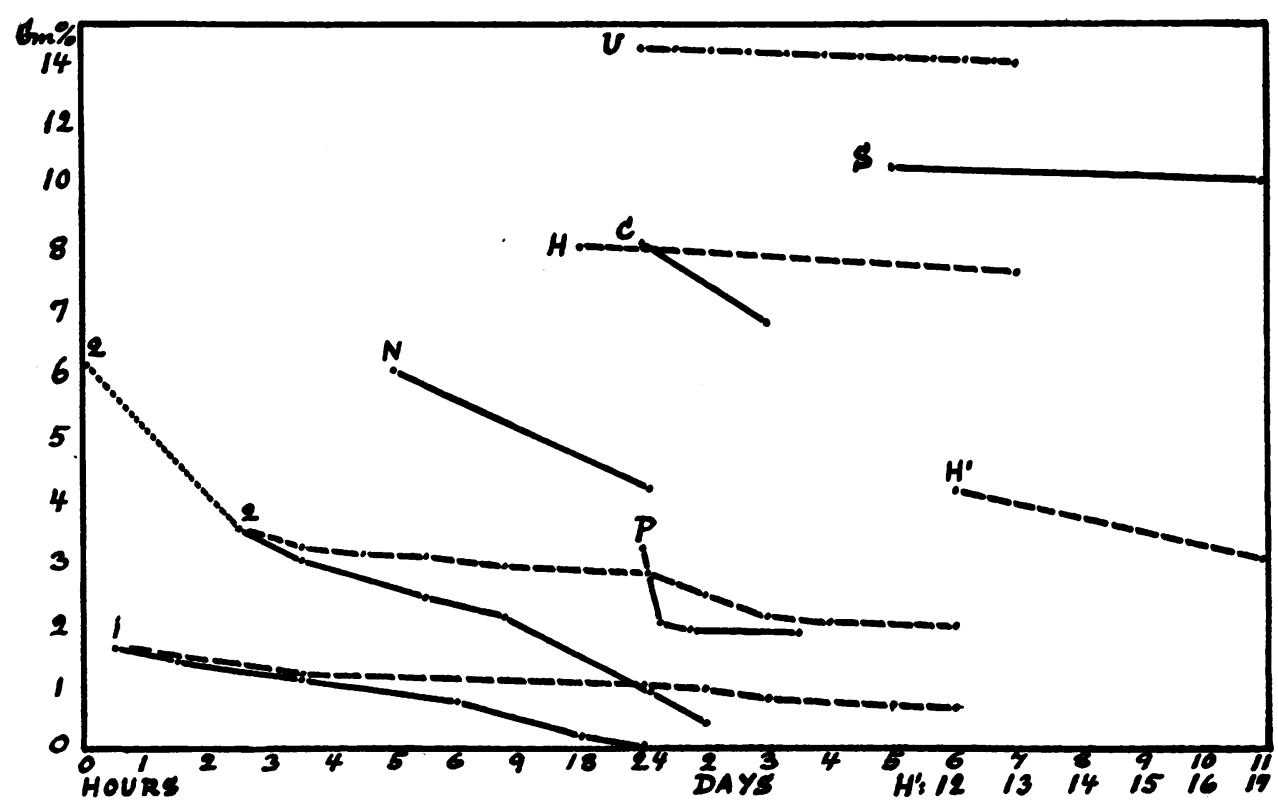

\title{
Fig. 1. Time Curfes of Postmortem Glycogenolysis of Various Diseased Tissues (cf. TABLE I)
}

\begin{abstract}
C. - - - Intact tissue at ice box temperature. -... Pulped tissue at ice box temperature. 1= Liver of Case 1, pancreatogenic hyperinsulinism. 2= Liver of Case 2, "neurogenic" hyperinsulinism (dotted line between biopsy and autopsy). $P=$ Liver of Popper and Wozasek's insulin-treated infant with diarrhea (sliced tissue, phosphate buffer, $\mathrm{pH}$ 6.9). $S=$ Liver of Schoenheimer-von Gierke's case of glycogen disease. $U=$ Liver of Unshelm's case of glycogen disease. $C=$ Heart of van Creveld's case of glycogen disease. $H, H^{\prime}=$ Heart and liver, respectively, of Hertz' case of glycogen disease. $N=$ Liver of Neuteboom's operated rabbit (see text).
\end{abstract}

of normal human livers obtained $2 \frac{1}{2}$ hours after death and no such figures have been published in the literature, we entirely depend upon the higher experimental animals for normal controls of postmortem hepatic glycogenolysis. Two experiments carried out in normal rats and one in a glucosefattened rabbit are recorded in Table I and Figure 2. Moreover, experiments made in cats (14), in a goat and a macacus rhesus (13), and in guinea pigs and rabbits (12b) are presented in Figure 2.8 In comparison with these animal experiments, postmortem glycogenolysis in human hyperinsulinism, as observed at $37^{\circ} \mathrm{C}$., proceeded at a similar rate in Case 1 and apparently somewhat slower in Case 2; at ice box temperature it held a middle course between the various animals' curves.

By mechanical trauma, such as slicing of the tissue, postmortem glycogenolysis was accelerated in

8 Phosphate ions increase hepatic glycogenolysis (Figure $2, D, F)$. the 2 clinical cases. This corresponds to similar observations in animal experiments, including the writer's own. The same is true of the increase in Case 1 of postmortem hepatic glycogenolysis by adding highly concentrated bile salts to the suspended liver slices. The proportion of lyo- and desmo-glycogen in the 2 human livers was also approximately the same as in animal controls.

As is shown in the experiment made in the glucose-fattened rabbit (Table I, Figure 2), high liver-glycogen content does not in itself inhibit postmortem glycogenolysis. This was demonstrated earlier by Kimmelstiel (15) in a dog put on "glycogen mast" whose liver glycogen disappeared completely at ice box temperature within 5 days after death. Less active, though distinct glycogenolysis was found by Popper and Wozasek (12b) in rabbits' livers rich in glycogen which were placed in the ice box either directly after death or following a 4-hour incubation at $37^{\circ} \mathrm{C}$. 


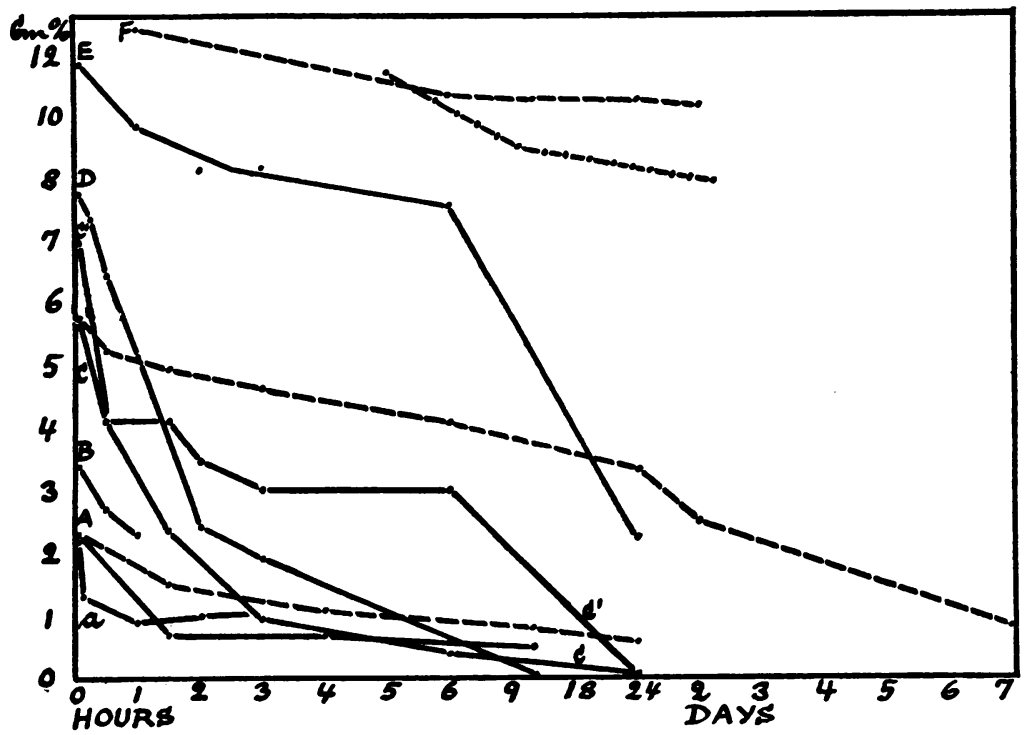

Fig. 2. Time Curves of Postmortem Hepatic Glycogenolysis of Normai Experimental Animals

. Intact tissue at $37^{\circ} \mathrm{C}$. - - - Intact tissue at ice box temperature. ..... Pulped tissue at ice box temperature. $a=$ Cat (Evans et al., at " room temperature"). $A=$ Goat (Burghard and Paffrath). $B=$ Macacus Rhesus (Burghard and Paffrath $17^{\circ}$ C.). $C=$ Rat (Number 173 a, Table I). $C^{\prime}=$ Rat (Number 36, Table I). $D=$ Guinea Pig (Popper and Wozasek Number 3; sliced tissue, phosphate buffer, pH 6.9). $E=$ Rabbit (Number 189, Table I). $F=$ Rabbit (Popper and Wozasek Number 2; in the lower curve, the liver was kept at $37^{\circ} \mathrm{C}$. for 4 hours before being transferred to ice box temperature; phosphate buffer, $\mathrm{pH}$ 6.9).

(Figure 2, F). Mild hypoglycemia in spite of high liver-glycogen content was found in young dogs fed on "glycogen mast" (16).

\section{DISCUSSION}

There can be hardly any doubt that in the first case of spontaneous hypoglycemia we were dealing with a pancreatogenic hyperinsulinism originating from a carcinoma of the Langerhans islets with insulin producing metastases to the liver and other organs. In Case 2, this pathology was clearly excluded, thus leaving room for speculation as to the nature of a spontaneous hypoglycemia associated with a massive fibroma on top of the liver. Most probably, the anatomical localization of the liver tumor gives the clue to a satisfactory explanation. The right side fibroma may have exerted an immediate pressure on the right splanchnic nerves and the right celiac ganglion, thus blocking the sympathetic impulses to the liver. Such impulses are known to mobilize glycogen from the liver either by direct nervous stimulation (e.g. piqûre) or by indirect stimuli such as hypoglycemia (17) or adrenalin supply. If the splanchnic nerves are cut in cats, a decrease in blood sugar and an inhibition of glycogenolysis of surviving liver slices ensue (Evans, Tsai and Young (14)). This indicates a relative preponderance of antagonistic impulses such as insulin supply, i.e., relative neurogenic hyperinsulinism.

The following conclusions may be drawn from the chemical investigations presented in the 2 cases of spontaneous hypoglycemia, the one most probably due to pancreatogenic hyperinsulinism, the other possibly due to neurogenic hyperinsulinism:

(1) More than normal amounts of glycogen were accumulated in the liver and muscles; hypoglycemia, therefore, was not due to lack of glycogen depots.

(2) Liver glycogen was not abnormally fixed as so-called desmo-glycogen; therefore, hypoglycemia was not caused in this manner. 
(3) High liver-glycogen content does not lead by itself to such an inhibition of hepatic glycogenolysis as to produce severe seizures of spontaneous hypoglycemia.

(4) Postmortem hepatic glycogenolysis was proceeding at an almost normal or only slightly retarded rate; the glycogenolytic enzyme was therefore active on the livers' own glycogen.

(5) Reactions of postmortem hepatic glycogenolysis to varying temperature, mechanical insult and high bile-salt concentration were also normal.

(6) Clinically, nevertheless, liver and muscle glycogen depots were mobilized with difficulty through the normal stimuli such as severe hypoglycemia, adrenalin injections and, in Case 2, possibly also ether.

These observations made in 2 cases of hyperinsulinism are in good agreement with what is known of insulin physiology. According to this knowledge, one essential action of insulin on the living tissue, especially liver and muscle, consists of an inhibition of the glycogenolytic enzyme resulting in accumulation and fixation of glycogen. In animal experiments, various insulin doses, when added in vitro, were able to inhibit postmortem glycogenolysis of normal liver slices (9b) and muscle extracts (18). In the postmortem specimens of the 2 patients' livers such inhibition was present only to a limited degree. Otherwise, in human pathology, only modest inhibitions of postmortem hepatic glycogenolysis have also been observed in insulin-treated cases of infantile alimentary intoxication (Figure $1, P$ ), of diabetes mellitus, and schizophrenia $(12 \mathrm{~b}, \mathrm{c})$. In diabetic children injected with insulin for several months or years, a syndrome of enlarged abdomen, hepatomegaly, obesity, and retardation of growth has been described by Mauriac (19) and other French writers $(8 b)$.

If the clinical and chemical pathology of spontaneous hypoglycemia due to pancreatogenic hyperinsulinism is compared with von Gierke's glycogen disease, there are a number of striking similarities to be observed in the two pictures. Severe spontaneous hypoglycemia, glycogen accumulation in liver and muscles, and lack of blood sugar response to adrenalin injection are the chief among them. A minor common feature seems to be the stimulation of hepatic glycogenolysis by high bile- salt concentrations such as has been demonstrated in vitro in Case 1 ( $c f$. Seckel, 9a) and may also occur in vivo in glycogen disease when jaundice coincides with the disorder $(20,21,22)$, or bile acids are given by mouth to such children (23).

On the other hand, there are outstanding differences between the two diseases. First of all, liver glycogen accumulation is more spectacular in glycogen disease than in hyperinsulinism leading, as it does, to a tumorous enlargement of the organ. Furthermore, organs other than the liver are often involved in glycogen disease, e.g. heart and kidneys. However, accumulation of glycogen as such is by no means pathognomonic of glycogen disease. Similar or even larger amounts of available glycogen may be stored in the liver - to a far lesser degree in other organs-as a result of simple dietary measures (18 to 22.4 grams per cent in dogs $(11,16,24) ; c f$. rabbits, Figure 2) or continuous intravenous glucose infusions (upper limit in dogs 22 grams per cent (25)). The fundamental pathology of glycogen disease is rather the almost complete inhibition of postmortem glycogenolysis of the organs affected. For a week or longer, practically no glycogen disappears from the organs, both at $37^{\circ} \mathrm{C}$. in an intact state $(8,26)$ and at ice box temperature in an intact as well as a pulped state $(27,28$, Table 1, Figure 1). Only in Hertz' (28) case of a young baby, heart and liver showed a rather active postmortem glycogenolysis when pulped and suspended in a phosphate buffer at $\mathrm{pH} 6.9$ and $37^{\circ} \mathrm{C}$. for 1 or 2 days. The active postmortem glycogenolysis in the intact liver and muscles of Karlstroem's (29) baby (Case 1) indicates, along with an incomplete chemical picture, the presence of either an undeveloped stage or an atypical variety of glycogen disease ( $c f$. Karlstroem's Case 2). In typical, fully-developed cases of glycogen disease, under natural circumstances, the glycogenolytic enzyme does not act after death on the tissues' own glycogen. This fundamental characteristic of glycogen disease has been shown to be missing in pancreatogenic hyperinsulinism. Here, certainly, we are dealing with the main distinguishing feature between the two diseases. Other specific symptoms of glycogen disease are the absence or rareness of hypoglycemic seizures, high insulin sensitivity, constant 
fasting ketonuria, high blood glycogen, hypercholesterinemia, and increased basal metabolism (30b).

From the observations presented in this paper we arrive at the conclusion that pancreatogenic (as well as therapeutic) hyperinsulinism is not identical with typical glycogen disease and, consequently, that typical glycogen disease cannot possibly originate from pancreatogenic hyperinsulinism alone.

This does not mean to say that a certain degree of pancreatogenic hyperinsulinism in conjunction with other endocrine disturbances could not play a part in the pathogenesis of glycogen disease. There are, for instance, 3 autopsy reports in the literature concerning partial enlargement and abundance of the Langerhans islets in von Gierke's Disease $((15,31)$, and Krakower's Case 1 (32)). Familial relations to diabetes mellitus are mentioned in 3 cases ( $(21)$, Harnapp's Case 2 (30a), Ellis' Case 1 (33)). Furthermore, the opinion has been offered that the insulin-treated cases of puerile diabetes resulting in hepatomegaly, obesity, and retardation of growth may represent a transition from diabetes into secondary glycogen disease (34). Conversely, Parnas and Wagner's (3) case of glycogen disease turned into diabetes mellitus at the age of 16 . On the other hand, the patient of WorsterDrought's (4b) appeared to be almost completely cured after puberty. These puberty changes occurring in glycogen disease, put together with the clinical and pathological reports of insular, thyrogenic, hypophyseal and adrenal ${ }^{4}$ disturbances, seem to point to a pluriglandular disbalance with an overfunction of the insulin apparatus as to the most probable pathogenesis of glycogen disease.

Finally, the question arises whether glycogen disease may not be an example of neurogenic hyperinsulinism. This opinion has lately been advanced by Neuteboom (35). He distinguished 2 "pure types of primary hepatomegalia glycogenica." The first type is represented by typical glycogen disease of the von Gierke-van Creveld description, consisting of a "hypofunction of the

- In in vitro experiments with cortical extract, the writer recently found a marked inhibition (up to 80 per cent) of the glycogenolysis of surviving rat liver slices. (To be published in "Endocrinology," 1939.) injured nerve tissue" (sympathetic pathways) with consequent "relative hyperinsulinism" and "insufficiency of the contrainsular system." For this type, no satisfactory experimental evidence was provided by Neuteboom. The observations made in Case 2 of this report seem to furnish arguments against the supposed identity of glycogen disease with this type of neurogenic hyperinsulinism. In sharp contrast to the first type, the second type of so-called glycogen disease consists of a "hyperfunction of the injured nerve tissue" with a consequent "real reactive hyperinsulinism." For this type, Neuteboom has offered clinical and experimental examples. Clinically, he presented a boy of 13 who early in life had twice suffered undefined injuries. Later, the liver became moderately enlarged. On the mere basis of a histological examination of a liver biopsy the diagnosis of glycogen disease was made (no glycogenolysis test!). Experimentally, spinal injuries were induced on a young rabbit by introducing platinum plates between the left I. and II. and the right V. and VI. thoracical segments. During life, the rabbit presented a picture in many respects similar to that of the boy; the liver and heart were enlarged and the blood glycogen was high. However, such fundamental symptoms as hypoglycemia, ketonuria, hypercholesterinemia, missing adrenalin response, and insulin sensitivity were absent or reversed in both the boy and the rabbit. After death, the animal's liver and heart were 30 and 40 per cent oversize, respectively. Liver glycogen examined 5 hours after death was 5.99 grams per cent (control rabbit 2.25); the heart was not rich in glycogen. Postmortem hepatic glycogenolysis, estimated only from 5 to 26 hours after death, was about as active as in our patient, Case 2, with possible neurogenic hyperinsulinism (Table I, Figure 1). Most interesting as these observations may be, they apparently do not justify the identification of either type of neurogenic hyperinsulinism with typical von Gierke's glycogen disease.

\section{SUMMARY}

In 2 adult cases of spontaneous hypoglycemia, the one probably due to pancreatogenic hyperinsulinism (Case 1: carcinoma of the Langerhans islets with liver metastases), the other possibly due 
to neurogenic hyperinsulinism (Case 2: massive fibroma on right top of the liver), there has been demonstrated a comparatively high liver and muscle glycogen content and an approximately normal or only slightly decreased postmortem hepatic glycogenolysis.

Since typical cases of glycogen disease are characterized by an abundance of glycogen accumulated in the liver and other organs and an almost complete inhibition of postmortem glycogenolysis in those organs, neither form of hyperinsulinism is identical with typical glycogen disease and, consequently, typical glycogen disease cannot originate from either form of hyperinsulinism.

\section{BIBLIOGRAPHY}

1. von Gierke, E., Hepato-Nephromegalia Glycogenica (Glykogenspeicherkrankheit der Leber und Nieren). Beitr. z. path. Anat. u. z. allg. Path., 1929, 82, 497.

2. Wilder, R. M., Allan, F. N., Power, M. H., and Robertson, H. E., Carcinoma of islands of pancreas. Hyperinsulinism and hypoglycemia. J. A. M. A. 1927, 89, 348.

3. Parnas, J. K., and Wagner, R., (a) Beobachtungen über Zuckerneubildung. Biochem. Ztschr., 1922, 127, 55; (b) Ueber eine eigenartige Störung des Kohlerhydratstoffwechsels und ihre Beziehungen zum Diabetes mellitus. Ztschr. f. d. ges. exper. Med., 1921, 25, 361.

4. Worster-Drought, C., (a) Case of enlarged liver with persistent acetonuria and diaceturia. Proc. Roy. Soc. Med., Sect. Dis. Child., 1923, 16, 56; (b) Hepatomegaly with persistent ketonuria. Ibid., 1935, 28, 829.

5. Snapper, I., and van Creveld, S., Un cas d'hypoglycémie avec acétonémie chez un enfant. Bull. et mém. Soc. méd. d. hôp. de Paris, 1928, 52, 1315.

6. Good, C. A., Kramer, H., and Somogyi, M., Determination of glycogen. J. Biol. Chem., 1933, 100, 485.

7. Somogyi, M., Sugar determination. J. Biol. Chem., 1926, 70, 599.

8. van Creveld, S., (a) Investigations on glycogen disease. Arch. Dis. Childhood, 1934, 9, 9; (b) Glycogen disease. Medicine, 1939, 18, 1.

9. Seckel, H. P. G., (a) The influence of various physiological substances on the glycogenolysis of surviving rat liver: methods; influence of the bile salts. Endocrinology, 1938, 23, 751; (b) Idem: Influence of insulin added in vitro. Ibid., 1938, 23, 760.

10. Willstätter, R., and Rohdewald, M., Ueber den $\mathrm{Zu}$ stand des Glykogens in der Leber, im Muskel und in Leukocyten (zur Kenntnis der Proteinbindung physiologisch wichtiger Stoffe). Ztschr. f. physiol. Chem., 1934, 225, 103.
11. Schönen, $H$., Untersuchungen über den Einfluss der Art und Menge der Nahrung auf die Organzusammensetzung und das Stoffwechselgeschehen in verschiedenen Altersstufen. Arch. f. d. ges. Physiol., 1932, 230, 179.

12. Popper, H., and Wozasek, O., (a) Zur Kenntnis des Glykogengehaltes der Leichenleber. Wien. Med. Wchnschr., 1929, 79, 456 ; (b) Idem. Ztschr. f. d. ges. exper. Med., 1932, 83, 682 ; (c) Ueber Diastasehemmung in der Leber bei tödlich verlaufender Insulin-Hypoglykämie. Virchows Arch. f. path. Anat., 1933, 288, 673.

13. Burghard, E., and Paffrath, H., Untersuchungen über den Glykogengehalt der Leber; kritische Untersuchungen über die Methodik der Glycogen- und Kohlehydratbestimmung der Leber. Ztschr. f. Kinderh., 1927, 45, 68.

14. Evans, C. L., Tsai, C., and Young, F. G., Behaviour of liver glycogen in experimental animals; methods : effect of ether and amytal. J. Physiol., 1931, 73, 67.

15. Kimmelstiel, P., Ueber Glykogenose. Beitr. z. path. Anat. u. z. allg. Path., 1933, 91, 1.

16. Junkersdorf, P., Glykogenspeicherung und Glykogenspeicherungskrankheit. Klin. Wchnschr., 1933, 12, 899.

17. Macleod, J. J. R., The Fuel of Life. Princeton University Press, Princeton, 1928, p. 50.

18. Lehmann, $H$., Action of insulin in cell-free extracts. Nature, 1938, 141, 690.

19. Mauriac, P., Hépatomégalies de l'enfance avec troubles de la croissance et du métabolisme des glucides. Paris Méd., 1934, 2, 525.

20. Warner, E. C., Case of hepatomegaly due to von Gierke's disease. Lancet, 1933, 1, 1070.

21. Sundal, A., Glycogenosis (von Gierke's Krankheit). Acta Paediat., 1936, 19, 80.

22. Anderson, P. M., Glycogen accumulation disease. Med. J. Austral., 1935, 22 (i), 362.

23. Linneweh, F., Zur Pathogenese der Glykogenkrankheit. Monatsschr. f. Kinderh., 1937, 70, 238.

24. Schöndorff, B., Ueber den Maximalwerth des Gesammtglykogengehalts von Hunden. Arch. f. d. ges. Physiol., 1903, 99, 191.

25. Butsch, W. L., Glucose tolerance and glycogen storage capacity of dog. Am. J. Physiol., 1934, 108, 639.

26. Schönheimer, R., Ueber eine eigenartige Störung des Kohlehydratstoff wechsels. Ztschr. f. physiol. Chem., 1929, 182, 148.

27. Unshelm, E., Die Glykogenkrankheit (Zugleich ein Beitrag zur Frage des hepatogenen Infantilismus). Jahrb. f. Kinderh., 1932, 137, 257.

28. Hertz, W., Untersuchungen über den vitalen und postmortalen Kohlehydratstoffwechsel bei Glykogenose und gestörter Schilddrüsentätigkeit. Ztschr. f. Kinderh., 1936, 58, 259.

29. Karlstroem, F., Glycogenosis. Acta Paediat., 1938, 20, 497. 
30. Harnapp, G. O., (a) Zur Klinik der Hepatomegalien mit Kohlehydratstoffwechselstörungen. I. Glykogenspeicherungskrankheit. Monatsschr. f. Kinderh., 1936, 66, 169; (b) Idem. III. Differentialdiagnose und Pathogenese der Glykogenspeicherungskrankheit. Ibid., 1936, 66, 194.

31. Esser, M., and Scheidegger, S., Glykogenkrankheit. Beobachtung eines Falles. Schweiz. Med. Wchnschr., 1937, 18, 970.
32. Krakower, C., The lipoid factor in glycogen storage disease. J. Pediat., 1936, 9, 728.

33. Ellis, R. W. B., Extreme hepatomegaly in an infant. Proc. Roy. Soc. Med., 1933, 27, 118.

34. Gjuric, A., cited by Creveld (8b).

35. Neuteboom, J. J., (a) Bijdrage tot de kennis der hepatomegalia glycogenica. W. D. Meinema, Thesis, Utrecht, Holland, 1937. (b) Zur Kenntnis der Glykogenkrankheit. Klin. Wchnschr., 1938, 17, 1437. 